\title{
GYULAFEHÉRVÁRI RÓMAI KATOLIKUS PAPNEVELŐ INTÉZET
}

Gyulafehérvári Római Katolikus Papnevelő Intézet

Cím: Gyulafehérvár, Bethlen Gábor utca 3.

Honlap: https://www.seminarium.ro

E-mail: teologiasis@gmail.com

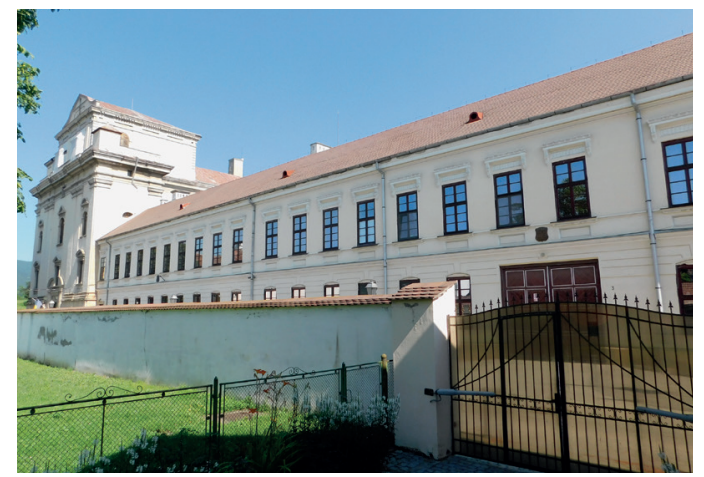

Gyulafehérváron a katolikus papképzésnek mély gyökerei vannak, a papnevelés története szorosan összekapcsolódik az erdélyi egyházmegye újjászületésével.

A Megtestesült Bölcsességről elnevezett szemináriumot (Seminarium Incarnatae Sapientiae) 1753-ban Báró Sztoyka Zsigmond Antal püspök alapította és látta el szabályokkal. A püspök állandó papnevelőházat építtetett, a Jerikó néven ismert épület helyén. Az intézmény alapítását követően az utód főpásztorok legfontosabb tennivalójuknak a papképzést tekintették. A papnevelés első újjászervezése Bajtai J. Antal püspök nevéhez köthető. Kollonitz László püspök 1778-ban átköltöztette a Papneveldét a volt jezsuita kollégiumba. Amikor II. József 1783-ban bezáratta a szemináriumot, a kispapok Kolozsvárra, majd Pestre kerültek. Batthyány Ignác püspök 1792-ben újra megnyitotta a Papneveldét, a jelenlegi helyén, az egykori gyulafehérvári trinitárius rendházban. Rudnay Sándor püspök Gyulafehérvárra rendelte a ferences növendékeket is, hogy a Teológián tanulhassanak. A kispapok belső életére és a szeminárium szervezetére vet fényt az 1822-es egyházmegyei zsinat határozatai. Szepesy Ignác püspök megreformálta a papnevelést, lecserélte a régi tankönyveket, előírta a könyvtár leltározását. Az 1848-49-es pusztítások súlyosan érintették a Papneveldét, épületeit lefoglalták, a kispapokat hazaküldték. Haynald Lajos püspök nagy figyelmet fordított a Teológia kézikönyvtárára, amely papi hagyatékokból és a Batthyány könyvtár duplumaiból gyarapodott. Fogarasy Mihály püspök alapítványt tett egy három fakultású egyetem (köztük a Teológia kar) létrehozására. Az állami tanügyi reformok értelmében a két éves filozófiai kurzust létesítette. Mivel a szeminárium épülete elégtelen volt, 1877-ben építtette

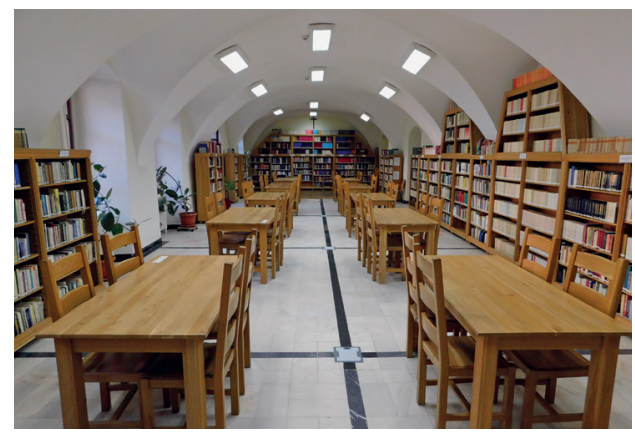




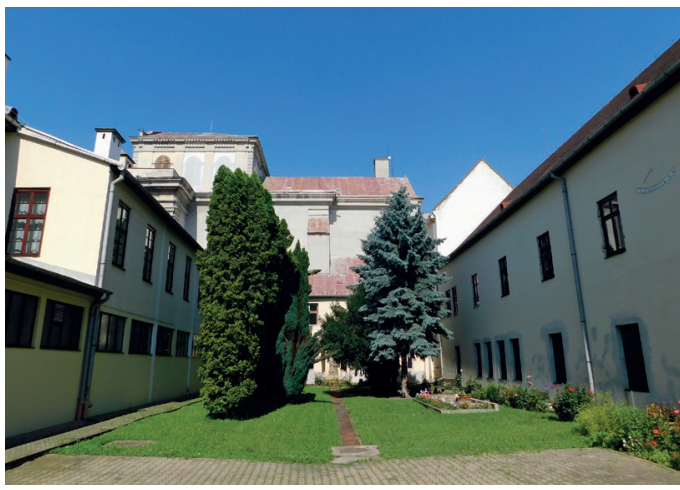

a Teológia utca felőli új szárnyát, ahol azóta is folyik az oktatás. A 20. század viharos történetében a Papnevelde is változásokon ment keresztül. A Majláth G. Károly püspök által tervezett új papneveldei épület felépítése nem valósult meg. 1918 után átlagban 40-60 kispap tanult a Papnevelde négy évfolyamán. Az 1934/35-ös tanévtől kezdve a papképzés ötéves, majd az 1947/1948-as tanévtől hatévfolyamos lett. Az 1948-as kultusztörvény súlyosan érintette a romániai teológiai oktatást, csak a gyulafehérvári Papnevelő Intézet működését engedélyezte. A közös Papnevelde újjászervezésében fontos szerepet játszott Márton Áron püspök. Börtönből való szabadulása után (1955) az egyházmegyék közötti Teológia felvirágzott, annak ellenére, hogy az állami hatóságok akadályozták az utánpótlást.

A rendszerváltást követő években a Papnevelde a Pápai Lateráni Egyetemmel társult. Tíz év múlva, a 2007/2008. tanévtől a Kolozsvári Babeș-Bolyai Tudományegyetem, Római Katolikus Kar Pasztorál Teológiai Intézeteként működik.

A Papnevelő Intézet részletes története Dr. Marton József Papnevelés az erdélyi egyházmegyében 1753-tól 1918-ig ${ }^{1}$ című könyvében olvasható. A 250 éve alapított Gyulafehérvári Papnevelde jubileuma alkalmával kiadott emlékkönyv feltárja Erdély legfontosabb katolikus intézményének történetét. ${ }^{2}$

\footnotetext{
${ }^{1}$ MARTON József: Papnevelés az erdélyi egyházmegyében 1753-tól 1918-ig. Budapest, Márton Áron Kiadó, 1993.

2 MARTON József (szerk.): Seminarium Incarnatae Sapientiae. Jubileumi emlékkönyv. Gyulafehérvár 1753-2003. Kolozsvár, Stúdium Könyvkiadó, 2003.
}

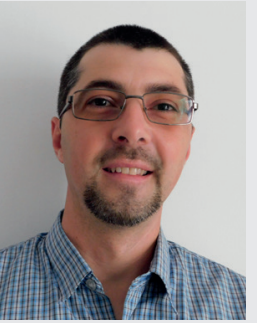

dr. Nagy József Gábor

2018-tól könyvtáros-levéltáros a Gyulafehérvári Római Katolikus Papnevelő Intézetben. 2015 és 2018 között régész a gyulafehérvári Nemzeti Egyesülés Múzeumban. 2014-ben főtanácsadó a Kulturális és Örökségvédelmi Minisztérium Kolozs Megyei Igazgatóságán. 2010 és 2013 között kutatási asszisztens, majd 2012-tól óraadó oktató a Kolozsvári Babeș-Bolyai Tudományegyetemen. 